\title{
Successful partnerships are the key to improving Aboriginal health
}

\author{
Sandra Bailey ${ }^{\mathrm{A}}$ and Jennifer Hunt ${ }^{\mathrm{A}, \mathrm{B}}$ \\ ${ }^{A}$ Aboriginal Health and Medical Research Council of NSW \\ ${ }^{\mathrm{B}}$ Corresponding author.Email: jhunt@ahmrc.org.au
}

work to a set of goals and targets developed in partnership with the Aboriginal community. Partnerships provide the most effective mechanism for obtaining this essential input from Aboriginal communities and their representative organisations, enabling Aboriginal people to have an influence at all stages of the health-care process.

Within the health sector, productive partnerships can effect positive change by harnessing the efforts of governments and health providers, along with the experience and expertise of Aboriginal Community Controlled Health Services (ACCHSs). ACCHSs are not only the most effective means of delivering comprehensive primary health care to Aboriginal people ${ }^{2}$ but are also a critical component of the overall health system. ${ }^{3,4}$ Such partnerships are designed to bring the experience and expertise of the Aboriginal community to bear at every level of the health-care system, including the identification of key issues, the development of policy solutions and the structuring and delivery of services.

However, a practical approach to partnership also means recognising that all parties in a partnership are not the same, that there are different roles and responsibilities - and different accountabilities. With consultations and submissions for the development of the 10-year Aboriginal Health Plan for NSW currently underway, the Aboriginal Health and Medical Research Council of NSW (AH\&MRC) believes it worthwhile to highlight in this article some of the key attributes of successful partnerships, both in general and specifically with the ACCHS sector.

\section{Advocating a partnership approach}

A partnership approach has long been advocated by government and ACCHSs as essential to addressing Aboriginal health inequity. In 1989, Australia developed its first National Aboriginal Health Strategy, which was the result of extensive consultations with Aboriginal communities and governments around the country. ${ }^{5}$ Before the development of this national strategy, the Commonwealth Government had no strategic approach to tackle the challenges surrounding Aboriginal health.

The Strategy not only reinforced the important role of ACCHSs in improving Aboriginal health, it also criticised the ad hoc approaches to Aboriginal health which were then prevalent. With a mandate to improve coordination and achieve better health outcomes, the National Aboriginal Health Strategy strongly recommended better partnerships 
between Commonwealth and state governments, and between the Aboriginal community and government at all levels.

Following the recommendations set out in the National Aboriginal Health Strategy, in 1995 the AH\&MRC and the NSW Government led the country by establishing the first NSW Aboriginal Health Partnership Agreement. ${ }^{6}$ Guided by the principle of self-determination, the Agreement emphasises a partnership approach and the importance of intersectoral collaboration. The Agreement also recommends that the partnership model be replicated at all levels of the health-care process, down to regional and local levels. Launched with bipartisan support, the NSW Aboriginal Health Partnership Agreement endures today and its founding principles remain unchanged.

In addition to the establishment of the NSW Aboriginal Health Partnership Agreement, in 2010 the NSW Government signed The Statement of Intent to Achieve Equality in Health Status and Life Expectancy Between Aboriginal and Torres Strait Islander Peoples and Non-Indigenous Australians. ${ }^{7}$ As with the NSW Aboriginal Health Partnership Agreement, the Statement of Intent also achieved bipartisan support in committing the NSW Government to work in new, more productive partnerships with Aboriginal people and their representative organisations.

\section{Partnerships and self-determination}

There are sound reasons why such initiatives recommend partnerships with Aboriginal communities and their representative organisations: the benefits of adopting a partnership approach are well documented, both in Australia ${ }^{8-10}$ and internationally. ${ }^{11,12}$

Within a local context, a partnership approach that incorporates proper recognition of the right of self-determination for Aboriginal people offers a solid foundation for improving collaborative efforts in the area of Aboriginal health.

The United Nations Declaration on the Rights of Indigenous Peoples lays out the principles of self-determination. Adopted in 2007, the Declaration upholds the rights of Indigenous peoples and calls on states to consult and cooperate in good faith with the peoples concerned through their own representative institutions in order to obtain their 'free, prior and informed consent before adopting and implementing legislative or administrative measures that may affect them.' 13 The Declaration defines the concept of self-determination for Indigenous peoples, in Articles 3, 4 and $5:^{13}$

\section{Article 3}

Indigenous peoples have the right to self-determination. $B y$ virtue of that right they freely determine their political status and freely pursue their economic, social and cultural development.

\section{Article 4}

Indigenous peoples, in exercising their right to selfdetermination, have the right to autonomy or selfgovernment in matters relating to their internal and local affairs, as well as ways and means for financing their autonomous functions.

\section{Article 5}

Indigenous peoples have the right to maintain and strengthen their distinct political, legal, economic, social and cultural institutions, while retaining their right to participate fully, if they so choose, in the political, economic, social and cultural life of the State.

Partnerships with Aboriginal organisations are far more likely to be successful if the principle of self-determination for Aboriginal people and their community organisations is honoured. ${ }^{14-16}$ Indeed, self-determination is the principle upon which the ACCHS sector was founded, extending traditions that are thousands of years old, wherein Aboriginal people have long maintained the health and wellbeing of their own communities. The first ACCHS were established in Australia 40 years ago on the basis that Aboriginal people needed to take health matters into their own hands as mainstream services continued to fail to help their communities. $^{17,18}$

There is substantial evidence to support the proposition that health benefits follow self-determination, which can yield positive reinforcement, cultural empowerment, improved self-esteem and better overall health outcomes. ${ }^{19-22}$

\section{Key principles of successful partnerships}

The term partnership is very common these days, but it can mean very different things to different people. The principles of effective partnerships in the area of Aboriginal health have been recently articulated by the National Aboriginal Community Controlled Health Organisation (NACCHO), together with the Australian Human Rights Commission (previously the Human Rights and Equal Opportunity Commission), Oxfam and other organisations involved in the National Close the Gap campaign:

Genuine partnership exists when two or more parties join together to work toward a common goal; it is a process of shared decision making, of negotiated outcomes, and of mutual respect. It is an ongoing process, and one that requires sustained effort to maintain over time. At its heart, working in partnership means that both parties have genuine influence - not only in identifying issues and developing solutions, but also in determining the form of partnership. ${ }^{23}$ 
In short, partnership is more than consultation and more than acting in an advisory capacity. A successful partnership requires considerable time and effort to develop, and should occur at all stages, from initiation to development to implementation and evaluation.

Key characteristics of successful partnerships include ${ }^{23}$ :

- Respect, trust and mutual understanding between all partners

- An acceptance that different parties will have different roles and responsibilities

- Provision of adequate resources to all partners

- Realistic and specific objectives, usually ones that each partner organisation would not be able to meet by working alone

- A process of review and evaluation, which is both qualitative and quantitative, and which assesses the partnership process as well as its outcomes.

Successful partnerships can also be defined by what they are not. Healthy, productive partnerships do not involve ${ }^{23}$ :

- Approaches that rely only on advisory boards and closed-door decision making

- One party independently deciding on a course of action and presenting it to the other for ratification

- Partners making public statements or developing new initiatives independently and without having first discussed the issue with the other partner.

In addition to these characteristics, partnerships in the area of Aboriginal health will be meaningful only if they are transparent and involve the relevant bodies that represent Aboriginal people.

Partnerships are critical to achieve health equity for Aboriginal people, but in order for them to be productive close attention must be paid to any power imbalances that exist. Aboriginal organisations, for example, are frequently in the position of being in partnership arrangements with organisations that fund them, which inherently influences the function and dynamics of the partnership. ${ }^{24}$ This issue needs to be acknowledged and addressed from the outset if a partnership is to be equal.

\section{Common goals}

ACCHSs and mainstream health-care providers undoubtedly share the goal of improving Aboriginal health. The AH\&MRC advocates meeting this common goal by adopting a rights-based approach to Aboriginal health initiatives, one in which human rights provide a framework for addressing the consequences of the health inequality experienced by Aboriginal people. Partnerships that are informed by a rights-based approach employ human rights standards to guide policy making and to influence the design, delivery and monitoring and evaluation of health programs and services. ${ }^{25}$ These standards include recognising not only the underlying causes of health inequity, but also how these causes are interconnected to other issues. $^{25}$

Achieving health equity for NSW will require governments, the ACCHS sector and other health services to work together towards the goal of a NSW health system that is competent to provide good access and good care for Aboriginal people on the basis of strong partnerships with Aboriginal health organisations. Reaching this goal will require a partnership process that:

- embodies the principles of self-determination

- incorporates a human rights approach to redressing Aboriginal disadvantage and to provide sufficient government accountability

- describes clearly the services required to improve the health of Aboriginal peoples in NSW

- sets out the roles and responsibilities of staff, management, organisations and stakeholders at every level of the system.

\section{Conclusion}

To achieve sustainable progress in addressing health inequities, Aboriginal people must be recognised as distinct and equal partners not only in words but in action. By agreeing on a shared vision and by working strategically in partnership at every level, NSW can and will develop and expand the scope, versatility and capacity of health services to improve the health of Aboriginal people.

\section{References}

1. NSW Health. Towards an Aboriginal Health Plan for NSW. Some challenges seen through new eyes. Consultation 2011. Available at http://www.health.nsw.gov.au/publichealth/ aboriginal/plan/index.asp (Cited 16 January 2012).

2. Peiris DP, Patel AA, Cass A, Howard MP, Tchan ML, Brady JP et al. Cardiovascular disease risk management for Aboriginal and Torres Strait Islander peoples in primary health care settings: findings from the Kanyini Audit. Med J Aust 2009; 191: 304-9.

3. Larkins SL, Geia LK, Panaretto KS. Consultations in general practice and at an Aboriginal Community Controlled Health Service: do they differ? Rural Remote Health 2006; 6(3): 560. Available at: http://www.rrh.org.au/articles/subviewnew.asp? articleid $=560($ Cited 21 March 2012)

4. Lutschini M. Engaging with holism in Australian Aboriginal health policy - a review. Australia and New Zealand Health Policy, 2, 2005. Available at: http://archive.biomedcentral.com/ 1743-8462/content/2/1/15 (Cited 21 March 2012)

5. National Aboriginal Health Strategy Working Party. A National Aboriginal Health Strategy 1989. Canberra: Australian Government Department of Health and Ageing; 1989. Available at: http://www.health.gov.au/internet/main/publishing.nsf/ Content/health-oatsih-pubs-NAHS1998 (Cited16 January 2012).

6. Aboriginal Health and Medical Research Council of New South Wales and NSW Health. NSW Aboriginal Health Partnership 
Agreement. Sydney: AH\&MRC, 2001. Available at: http:// www.ahmrc.org.au/index.php?option=com_content\&view= article $\&$ id $=33$ :our-partners\&catid $=4$ :about-ahmrc $\&$ Itemid $=13$ (Cited 15 March 2012).

7. NSW Government. The statement of intent to achieve equality in health status and life expectancy between Aboriginal and Torres Strait Islander peoples and non-Indigenous Australians. Sydney: NSW Government; 2010. Available at: http://www.health.nsw. gov.au/resources/publichealth/aboriginal/pdf/signed_nsw_ statement_of_i.pdf (Cited 16 January 2012).

8. Murray R, Bell K, Elston J, Ring I, Frommer M, Todd A. Guidelines for the development, implementation and evaluation of National Public Health Strategies in relation to Aboriginal and Torres Strait Islander peoples: Approaches and Recommendations. Report for the National Public Health Partnership, February 2002. Available at: http://www.nphp.gov.au/publica tions/strategies/atsi_guidelines.pdf (Cited 16 January 2012).

9. Taylor KP, Thompson SC. Closing the (service) gap: exploring collaboration and partnership models between Aboriginal and mainstream organisations. Aust Health Rev 2011; 35: 297-308. doi:10.1071/AH10936

10. Waples-Crowe P, Pyett P. The making of a great relationship: a review of a healthy partnership between mainstream and Indigenous organisations. Melbourne: Victorian Aboriginal Community Controlled Health Organisation; 2005. Available at: http://www.vaccho.org.au/vcwp/wp-content/uploads/2011/03/ GreatrelationshipDocument.pdf (Cited 16 January 2012).

11. World Health Organization. The power of partnership. Global partnership to stop TB. Geneva: World Health Organization; 2003.

12. Hardy B. Hudson B, Waddington E. What makes a good partnership? A partnership assessment tool. Leeds: Nuffield Institute for Health; 2000. p. 9.

13. United Nations General Assembly. United Nations Declaration on the Rights of Indigenous Peoples. A/RES/61/295. 13 September 2007. Available at: http://un.org/esa/socdev/unpfii/en/ declaration.html (Cited 16 January 2012).

14. Altman JC. Beyond closing the gap: valuing diversity in Indigenous Australia. Canberra: Centre for Aboriginal Economic Policy Research, ANU; 2009.
15. Franks A, Smith-Lloyd D, Newell S, Dietrich UC. Aboriginal health promotion self-determination project: background paper. Prepared for Health Promotion Unit, Northern Rivers Area Health Service, Lismore NSW; 2001.

16. Lee AJ, Bonson AP, Yarmirr D, O’Dea K, Mathews JD. Sustainability of a successful health and nutrition program in a remote Aboriginal community. Med J Aust 1995; 162: 632-5.

17. Hetzel BS. Historical perspectives on indigenous health in Australia. Asia Pacific J Clin Nutr 2000; 9(3): 157-63. Available at: http://211.76.170.15/server/APJCN/Volume9/vo19.3/Hetzel. pdf (Cited 21 March 2012)

18. Australian Indigenous HealthInfoNet. Summary of developments in Indigenous health promotion 2005. Available at http://www.healthinfonet.ecu.edu.au/health-systems/ health-promotion/reviews/our-review (Cited 15 March 2012)

19. Auerbach JA, Krimgold BK, Lefkowitz B. Improving health: it doesn't take a revolution. Washington: National Policy Association; 2000.

20. Cox E. Building social capital. Health Prom Matters 1997; 4: 1-4.

21. Newell S. Rekindling the Spirit: potential benefits for the North Coast Area Health Service. Report prepared for Rekindling the Spirit, Lismore NSW; 2008.

22. Garvey D. A review of the social and emotional wellbeing of Indigenous Australian peoples - considerations, challenges and opportunities. 2008. Available at: http://www.healthinfonet.ecu. edu.au/sewb_review (Cited 16 January 2012).

23. Chapman N. Close the Gap Steering Committee for Indigenous Health Equality. Partnership Position Paper, June 2010. Available at: http://www.hreoc.gov.au/pdf/social_justice/health/ partnership_position_paper.pdf (Cited 16 January 2012).

24. Dwyer J, O’Donnell K, Lavoie J, Marlina U, Sullivan P. The overburden report: contracting for indigenous health services. 2009. Cooperative Research Centre for Aboriginal Health, Darwin. Available at: http://www.crcah.org.au/publications/downloads/ overburden\%20report_FINAL.pdf (Cited 21 March 2012)

25. Aboriginal and Torres Strait Islander Social Justice Commissioner. Social Justice Report 2005. Report No 3/2005. Available at: http://www.hreoc.gov.au/social_justice/sj_report/sjreport05/ pdf/SocialJustice2005.pdf (Cited 16 January 2012). 